\title{
ACCUMULATION OF SODIUM AND HEAVY METALS IN SOIL CULTIVATED WITH Corymbia citriodora AFTER THE APPLICATION OF SWINE WASTEWATER
}

\author{
ACÚMULO DE SÓDIO E METAIS PESADOS NO SOLO CULTIVADO COM \\ Corymbia citriodora APÓS A APLICAÇÃO DE ÁGUA RESIDUÁRIA DE \\ SUINOCULTURA
}

\author{
Rafaella Ferreira Batista BERNARDES ${ }^{1}$; Regina Maria Quintão LANA ${ }^{2}$; \\ Laura Rayane Rodrigues OLIVEIRA ${ }^{3}$; Renato Aurélio Severino de Menezes FREITAS ${ }^{3}$; \\ Reginaldo de CAMARGO ${ }^{2}$; Danyela Cristina Marques PIRES ${ }^{1}$ \\ 1. Mestres em Agronomia pela Universidade Federal de Uberlândia-ICIAG-UFU, Uberlândia, MG, Brasil. \\ rafaellaferreiraagro@gmail.com; 2. Professores do Instituto de Ciências Agrárias da Universidade Federal de Uberlândia-ICIAG-UFU, \\ Uberlândia, MG, Brasil.rmqlana@ufu.br; 3. Agrônomos pela Universidade Federal de Uberlândia-ICIAG-UFU, Uberlândia, MG, \\ Brasil
}

\begin{abstract}
The confinement of pigs stands out as a great generator of swine wastewater (SW). The final destination of waste generated is currently a concern of society, since if handled improperly, it can cause serious impacts to the environment. One of the alternatives is the use of SW as a source of nutrients, which are made available to the plants, after the mineralization of organic matter. The objective of this work was to compare soil chemical attributes under two planting arrangements, in single and double lines of Corymbia citriodora. Two experiments were carried out at the Bonsucesso farm, in Uberlândia-MG, the first with $C$. citriodora in simple lines, with five plants per plot, spacing two meters between plants and 15 meters between rows. The second experiment was with $C$. citriodora in double lines, with two meters between plants in the line, three meters between lines in the plot and 15 meters between the double lines of $C$. citriodora. The statistical design was in randomized blocks. The treatments used were five doses of SW $(0 ; 200 ; 400 ; 600$ and $800 \mathrm{~m}^{3} \mathrm{ha}^{-1}$ ) with five replicates. The application of SW rates was divided in the dry season, in the months of June, July and August. The chemical characteristics of the soil were evaluated in the $0-20 \mathrm{~cm}$ depth layer. Planting on double lines of $C$. citriodora provided higher soil nutrient contents. The application of swine wastewater raised the levels of potassium and heavy metals such as copper and zinc. The dose of $200 \mathrm{~m}^{3} \mathrm{ha}^{-1}$ provided adequate levels for most nutrients present in the soil.
\end{abstract}

KEYWORDS: Pig slurry. Fertirrigation. Heavy metals. Soil salinization. Silvipastoral system.

\section{INTRODUCTION}

Pork is the most consumed animal protein in the world and domestic consumption in Brazil grows every year, reaching 80 to $85 \%$ of the national production (ABCS, 2017). The largest producing states in Brazil are Santa Catarina, Paraná, Rio Grande do Sul and Minas Gerais. With the increase in production, there is also an increase in the quantity of wastewater from swine (SW) (MAPA, 2014). SW can be used in agriculture as a source of nutrients for plants because of the presence of macronutrients and micronutrients, as well as organic compounds that help to improve the chemical, physical and biological characteristics of the soil (SEGRANFREDO, 2004). The use of SW as fertilizer added to the soil promotes mineralization of the elements that can be absorbed by plants in the same way as the mineral fertilizers.
When poorly managed and untreated, SW produces large amounts of waste with high nutrient loads such as potassium $(\mathrm{K})$, sodium $(\mathrm{Na})$, copper $(\mathrm{Cu})$ and zinc $(\mathrm{Zn})$, which can cause soil and subsurface waters contamination due to the presence of heavy metals such as $\mathrm{Cu}$ and $\mathrm{Zn}$, and also the presence of $\mathrm{Na}$, causing salinization (CERETTA et al., 2005; HESPANHOL, 2003). The presence of salts in the soil reduces the availability of water to the plants and may render soils unsuitable for cultivation (AYERS; WESTCOT, 1999). Therefore, studying the dose of SW applied to the soil to verify the most adequate amount to replenish the nutrients withdrawn by the plant, its contribution to soil fertility, minimizing the risks of soil contamination, are of fundamental importance for a productive and sustainable environment (DAL BOSCO, 2007). However, this use must be conditioned to the treatment of these waters, the type of crop, the 
choice of application methods and the control of risks to the environment (ABREU NETO, 2007).

Nowadays it requires a good production, with environmental care in every productive sector. In this context, silvopastoral systems are consolidated in this model of environmental conservation, where animal production, forage plants and trees are combined in the same area, to generate production in a complementary way through their interactions (FRANCO, 2015).

The commercial cultivation of eucalyptus species has gained great importance in the Brazilian economy, due to the multiplicity of its uses and the significant area of forests introduced in the national territory. Corymbia citriodora is a species of great importance in the Brazilian economy because it is less susceptible to soil and climatic variations. Its wood is used for the production of charcoal, posts and sawmill and the leaves are used in the commercial exploitation of essential oil extraction (DOGENSKI, 2013; ANDRADE; GOMES, 2000).

The objective of this work was to compare soil chemical attributes under two cropping arrangements, in single and double lines of Corymbia citriodora, in a silvopastoral system, at 0$20 \mathrm{~cm}$ depth, and to evaluate the variation in the chemical parameters of soil up to $60 \mathrm{~cm}$ depth in planting on double lines of Corymbia citriodora under different doses of pig wastewater.

\section{MATERIAL AND METHODS}

The work was carried out at Bonsucesso farm, located in the municipality of Uberlândia-MG, at the geographical coordinates, latitude $19^{\circ} 05^{\prime} 17^{\prime \prime} \mathrm{S}$, longitude $48^{\circ} 22^{\prime} 00^{\prime \prime} \mathrm{W}$ and average altitude of 820 meters. According to the classification system of Koppen, the climate of the region is characterized as being typical tropical type, with average precipitation around $1600 \mathrm{~mm}$ per year, presenting moderate water deficit in winter and excessive rainfall in summer.

Soil in the experimental area was classified as Dystrophic Red Latosol, according to Embrapa (2018) and is under Urochloa decumbens pasture.

The analysis was performed for chemical characterization (Tables 1 and 2), at 0-20 cm depth. The soil texture was composed of $31.0 \%$ of coarse sand, $48.8 \%$ of fine sand, $8.8 \%$ of silt and $11.4 \%$ of clay (EMBRAPA, 2018).

Table 1. Chemical characterization of the soil of the experimental area, Uberlândia-MG, 2014.

\begin{tabular}{|c|c|c|c|c|c|c|c|c|c|c|c|c|}
\hline Depth & $\mathrm{pH} \mathrm{H} \mathrm{H}_{2} \mathrm{O}$ & $\mathrm{P}$ & $\mathrm{K}$ & $\mathrm{Al}^{3+}$ & $\mathrm{Ca}^{2+}$ & $\mathrm{Mg}^{2+}$ & $\mathrm{H}+\mathrm{Al}^{3}$ & SB & $\mathrm{T}$ & $\mathrm{V}$ & $\mathrm{m}$ & $\mathrm{OM}$ \\
\hline $\overrightarrow{\mathrm{cm}}$ & & --1 & $m^{-3}-$ & $\ldots$ & 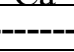 & $\mathrm{cmo}$ & $\mathrm{dm}^{-3}-$ & & & & & $\mathrm{g} \mathrm{kg}^{-1}$ \\
\hline$\overline{00-20}$ & 5.7 & 9.6 & 29 & 0.0 & 0.9 & 0.5 & 1.8 & 1.47 & 3.27 & 45 & 0 & 17 \\
\hline
\end{tabular}

$\mathrm{P}, \mathrm{K}=\left(\mathrm{HCl} 0.05 \mathrm{~mol} \mathrm{~L}^{-1}+\mathrm{H}_{2} \mathrm{SO}_{4} 0.0125 \mathrm{~mol} \mathrm{~L}^{-1}\right)$; Available $\mathrm{P}\left(\right.$ Mehlich $^{-1}$ extractor $) ; \mathrm{Ca}, \mathrm{Mg}, \mathrm{Al},\left(\mathrm{KCl} 1 \mathrm{~mol} \mathrm{~L}^{-1}\right) ; \mathrm{H}+\mathrm{Al}=(\mathrm{Buffer}$ Solution $-\mathrm{SMP}$ at $\mathrm{pH}$ 7.5); $\mathrm{SB}=$ Sum of Bases; $\mathrm{T}=\mathrm{CEC}$ at $\mathrm{pH} 7.0 ; \mathrm{V}=$ Base Saturation; $\mathrm{m}=$ Saturation by aluminum. $\mathrm{OM}=\mathrm{Organic}$ Matter by the Colorimetric Method (EMBRAPA, 2011).

Table 2. Micronutrient contents of the experimental area, Uberlândia-MG, 2014.

\begin{tabular}{llllll}
\hline Depth & $\mathrm{B}$ & $\mathrm{Cu}$ & $\mathrm{Fe}$ & $\mathrm{Mn}$ & $\mathrm{Zn}$ \\
\hline $\mathrm{cm}$ & -0.11 & 0.8 & 36 & 3.6 & 1.2 \\
\hline $0-20$ & 0.11 &
\end{tabular}

$\mathrm{B}=\left(\mathrm{BaCl}_{2} .2 \mathrm{H}_{2} \mathrm{O} 0.0125 \%\right.$ hot $) ; \mathrm{Cu}, \mathrm{Fe}, \mathrm{Mn}, \mathrm{Zn}=\left(\right.$ DTPA $0.005 \mathrm{~mol} \mathrm{~L}^{-1}+$ TEA $0.01 \mathrm{~mol}^{-1}+\mathrm{CaCl}_{2} 0.01 \mathrm{~mol} \mathrm{~L}^{-1}$ at pH 7.3). Clay: Pipette Method (EMBRAPA, 2013).

According to CFSEMG (1999) and Table 1, the $\mathrm{pH}$ is considered good, with acidity classified as average. In view of the results, it was not necessary to perform soil acidity correction.

Two spatial planting arrangements of Corymbia citriodora seedlings were carried out in single lines and double lines in December 2014. The spacing used in planting in simple lines was 2 meters between plants and 15 meters between the simple lines. Between lines, the Urochloa decumbens pasture was maintained. The plots consisted of 10 meters in length, containing 5 plants in each line, totaling 5 plants in the plot, by 3 meters wide, with an area of $30 \mathrm{~m}^{2}$.

The spacing used in planting C. citriodora in double lines was 2 meters between plants in the line plus 3 meters between rows and 15 meters between the double rows. Between the lines of the C. citriodora was the pasture of Urochloa decumbens. The plots consisted of 10 meters in length, containing 5 plants in each single line, totaling 10 plants in the plot, 6 meters wide, with an area of $60 \mathrm{~m}^{2}$.

The planting and cover fertilization for $C$. citriodora was performed according to the soil 
analysis and plant need, according to CFSEMG (1999). In the planting of the seedlings were used $100 \mathrm{~kg} \mathrm{ha}^{-1}$ of single superphosphate $\left(18 \%\right.$ of $\left.\mathrm{P}_{2} \mathrm{O}_{5}\right)$ applied in the planting line and the cover fertilization with $0.15 \mathrm{~kg}$ per plant of the formulation 20-00-20, at 90 and 150 days after planting. The control of weeds was done by manual weeding, at 60, 120 and 180 days after planting, in a range of $80 \mathrm{~cm}$ over the planting line.

The statistical design was a randomized block with 5 replicates. The treatments were four doses of swine wastewater (SW): 200, 400, 600 and
$800 \mathrm{~m}^{3} \mathrm{ha}^{-1}$, and a treatment without the application of SW. The applications were parceled out in June, July and August of 2015.

SW comes from pig farms at the Bonsucesso farm, with 6,000 pigs in the fattening phase, with an average volume of $110 \mathrm{~m}^{3}$ per day of SW. The manures are handled with PVC blanket biodigestor and stabilization pond, being stored for approximately 20 days. In all SW applications, samples were collected for the characterization of their chemical composition (Table 3).

Table 3. Chemical characterization of swine wastewater from a termination farm.

\begin{tabular}{lcccc}
\hline Parameter & Unit & $1^{\text {st }}$ application & $2^{\text {nd }}$ application & $3^{\text {rd }}$ application \\
\hline $\mathrm{pH}$ & & 7.00 & 7.40 & 7.40 \\
Density & $\%$ & 1.00 & 1.01 & 1.00 \\
Organic Matter $(\mathrm{OM})$ & $\%$ & 0.65 & 0.91 & 0.65 \\
Organic Carbon $(\mathrm{OC})$ & $\%$ & 0.36 & 0.05 & 0.36 \\
Total Nitrogen $(\mathrm{N})$ & $\%$ & 0.35 & 0.47 & 0.14 \\
Carbon/Nitrogen Ratio & $\%$ & 1.03 & 10.70 & 2.57 \\
Total Phosphorus $\left(\mathrm{P}_{2} \mathrm{O}_{5}\right)$ & $\%$ & 0.70 & 0.07 & 0.08 \\
Potassium soluble in water $\left(\mathrm{K}_{2} \mathrm{O}\right)$ & $\%$ & 0.36 & 0.18 & 0.36 \\
Calcium $(\mathrm{Ca})$ & $\%$ & 0.54 & 0.58 & 0.68 \\
Magnesium $(\mathrm{Mg})$ & $\%$ & 0.05 & 0.06 & 0.10 \\
Sulfur $(\mathrm{S})$ & $\%$ & 0.00 & 0.00 & 0.00 \\
Sodium $(\mathrm{Na})$ & $\mathrm{mg} \mathrm{L}$ & 200.00 & 300.00 & 700.00 \\
Copper $(\mathrm{Cu})$ & $\mathrm{mg} \mathrm{L}^{-1}$ & 5.00 & 6.00 & 15.00 \\
Zinc $(\mathrm{Zn})$ & $\mathrm{mg} \mathrm{L}^{-1}$ & 5.00 & 5.00 & 9.00 \\
\hline
\end{tabular}

After the first year of application of SW, three soil samples per plot were collected at $0-20 \mathrm{~cm}$ depth to evaluate the chemical properties of the soil. The soil samples were homogenized and placed in a forced air circulation oven at $45^{\circ} \mathrm{C}$ for 48 hours, characterized as greenhouse dry earth (GDE), crushed using a manual screwdriver, passed through a $2 \mathrm{~mm}$ diameter sieve to remove the clods and impurities. The chemical analyzes were performed based on the Embrapa (2011) methodology.

After all the assumptions were taken from the statistical point of view, the data were analyzed together with a regression for the SW dose variable and the $\mathrm{F}$ test for the $C$. citriodora planting lines, for the comparison of soil chemical analysis, using Statistical program SISVAR ${ }^{\circledR}$ (FERREIRA, 2000). For the joint analysis, only those characteristics whose residual mean squares did not differ by more than seven times from one experiment to the other were selected (GOMES, 1985). For the model adjustments and graphing, the SigmaPlot 10.0 computational application was used (SIGMA PLOT, 2015).

\section{RESULTS AND DISCUSSION}

\section{Potassium and sodium content in the soil}

The $\mathrm{K}$ content before the treatments was considered low and after the application of SW, regardless of the applied dose, the content was classified as very good, according to CFSEMG (1999). There was no interaction between SW doses and the type of arrangement adopted in the area (Table 4), with only significance for the SW doses, where the regression test was applied (Figure 1).

The maximum content of $\mathrm{K}$ in the soil in the planting of single lines of C. citriodora (A) was $151.7 \mathrm{mg} \mathrm{dm}^{-3}$ at a dose of $520 \mathrm{~m}^{3} \mathrm{ha}^{-1}$, an increase of $113.7 \%$ more than the treatment in which there was no SW application. For planting in double rows, the maximum content of $\mathrm{K}$ was $195.52 \mathrm{mg} \mathrm{dm}^{-3}$ at a dose of $671.83 \mathrm{~m}^{3} \mathrm{ha}^{-1}$, representing an increase of $207.42 \%$ more than the treatment without application of SW. Most of the K contained in pig feed is excreted by animals, where the average efficiency in nutrient use by pigs is $29 \%$ for nitrogen $(\mathrm{N})$ and phosphorus $(\mathrm{P})$, and $6 \%$ for $\mathrm{K}$ (BERTONCINI, 2011). 
At the highest applied dose of SW $\left(800 \mathrm{~m}^{3}\right.$ $\mathrm{ha}^{-1}$ ) in C. citriodora planting in single and double lines, there was a reduction in $\mathrm{K}$ content of $13.4 \%$ and $35.72 \%$, respectively. SW is a net source of nutrients, but it can cause leaching of these to deeper layers or even surface runoff in the soil, especially if the infiltration capacity is low and the volume of liquid is high. The volume of applied liquid of $800 \mathrm{~m}^{3} \mathrm{ha}^{-1}$, can be considered high, which could have caused the leaching of $\mathrm{K}$.

Table 4. Averages of $\mathrm{K}$, ratio of $\mathrm{K}$ and $\mathrm{CEC}$ at $\mathrm{pH} 7(\mathrm{~K} / \mathrm{T})$, and soil $\mathrm{Na}$ content, under two arrangements of $C$. citriodora, single line and double lines, with application of different doses of swine wastewater.

\begin{tabular}{|c|c|c|c|c|c|c|}
\hline \multirow{2}{*}{$\begin{array}{l}\text { Dose } \\
\mathrm{m}^{3} \mathrm{ha}^{-1}\end{array}$} & $\begin{array}{l}\mathrm{SL} \\
\mathrm{K}\end{array}$ & DL & $\begin{array}{l}\text { SL } \\
\text { K/T }\end{array}$ & $\overline{\mathrm{DL}}$ & $\begin{array}{l}\mathrm{SL} \\
\mathrm{Na}\end{array}$ & $\mathrm{DL}$ \\
\hline & $\mathrm{mg} \mathrm{dm}^{-3}$ & & $\%$ & & $\mathrm{mg} \mathrm{dm}^{-3}$ & \\
\hline 0 & 71.4 & 63.6 & $6.0 \mathrm{a}$ & $4.8 \mathrm{a}$ & 64.0 & 82.0 \\
\hline 200 & 121.2 & 121.2 & $6.2 \mathrm{a}$ & $8.7 \mathrm{a}$ & 196.0 & 288.0 \\
\hline 400 & 148.6 & 168.8 & $8.4 \mathrm{~b}$ & $13.8 \mathrm{a}$ & 298.0 & 342.0 \\
\hline 600 & 163.0 & 194.2 & $8.3 \mathrm{~b}$ & $17.1 \mathrm{a}$ & 364.0 & 476.0 \\
\hline 800 & 142.2 & 172.8 & $7.5 \mathrm{~b}$ & $11.6 \mathrm{a}$ & 340.0 & 396.0 \\
\hline Average & $129.3^{\mathrm{ns}}$ & $144.1^{\mathrm{ns}}$ & 7.3 & 11.2 & $252.4 \mathrm{a}$ & $317.0 \mathrm{~b}$ \\
\hline CV (\%) & 21.45 & & 23.13 & & 25.69 & \\
\hline
\end{tabular}

$(*)$ Values followed by lowercase letters in the line do not differ from each other by Tukey test $(\mathrm{P}<0.05)$. Lowercase letters refers to the comparison between the planting arrangements single lines (SL) and double lines (DL). Ns: not significant $(\mathrm{P}>0.05)$.

A

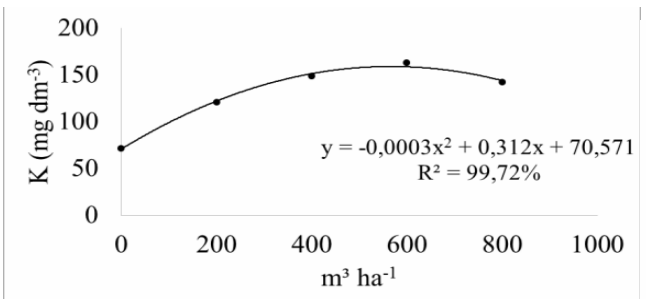

Figure $1 . \mathrm{K}$ content in the soil $\left(\mathrm{mg} \mathrm{dm}^{-3}\right)$, in single lines $(\mathrm{A}$ of swine wastewater doses.

The availability depends on the $\mathrm{K}$ forms present and the amount stored in each of these forms, which contributes to the movement and dynamics of $\mathrm{K}$ in the soil profile (WERLE; GARCIA; ROSOLEM, 2008). $\mathrm{K}$ is easily leached, especially in sandy soils. In this study, the soil is characterized as sandy ( $11 \%$ of clay), favoring the leaching of this cation.

Similar results were found by Homem et al. (2014), where the exchangeable K values of the soil

A

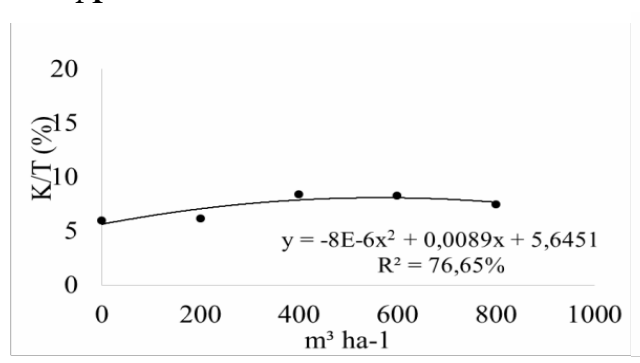

B

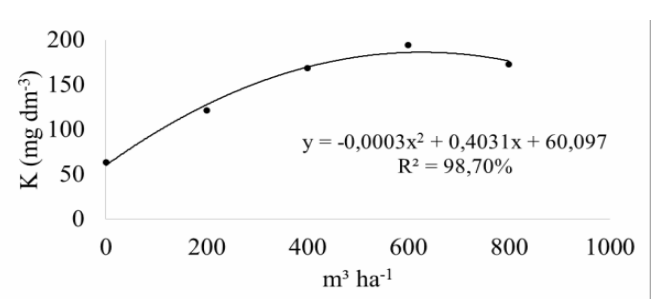

(A) and double lines (B) of C. citriodora, as a function presented statistical difference in the layer of 0-20 $\mathrm{cm}$, observing an increase in its content over the four-dose applications of SW $(0 ; 50 ; 100$ and 150 $\mathrm{m}^{3} \mathrm{ha}^{-1}$ ).

For the ratio of $\mathrm{K}$ and the cation exchange capacity at $\mathrm{pH} 7.0(\mathrm{~T}), \mathrm{K} / \mathrm{T}$, there was significance for the interaction of SW doses and the type of $C$. citriodora arrangement (Table 4 and Figure 2).

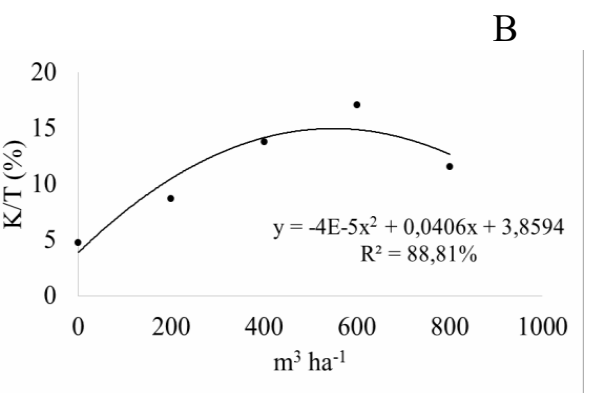

Figure 2. Ratio of $\mathrm{K}$ and cation exchange capacity at $\mathrm{pH} 7(\mathrm{~T})$ in the soil (\%), planting in single lines (A) and double lines (B) of C. citriodora, as a function of swine wastewater doses. 
The ideal $\mathrm{K} / \mathrm{T}$ ratio for most crops is $5 \%$, that is, $5 \%$ of the CEC loads at $\mathrm{pH} 7$ of the soil are occupied by $\mathrm{K}$. It is verified in this work that in both planting arrangements, after application of SW, for all applied doses, this ratio is above the recommended level. The dose of $600 \mathrm{~m}^{3} \mathrm{ha}^{-1}$, in the planting in double lines, found a $\mathrm{K} / \mathrm{T}$ ratio of $17.12 \%$, showing that the $\mathrm{K}$ contents are high in the soil, which may prevent or inhibit the retention of

A

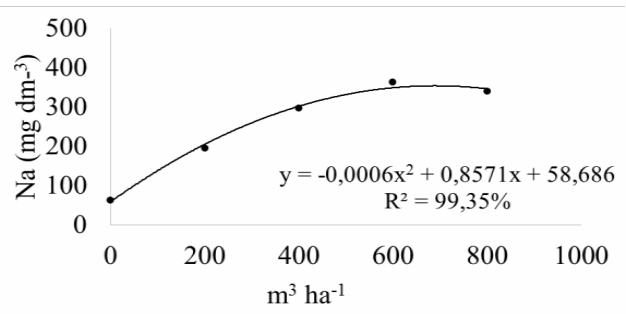

Figure 3. Na content in the soil $\left(\mathrm{mg} \mathrm{dm}^{-3}\right)$, in single lines (A) and double lines (B) of C. citriodora, as a function of swine wastewater doses.

There was an increase in soil $\mathrm{Na}$ concentration in the plantations in single and double lines, as the SW doses increased. In general, the concentrations of $\mathrm{Na}$ are high after the application of SW, mainly in the superficial layers. High concentrations of $\mathrm{Na}$ in the soil solution, compared to $\mathrm{Ca}$ and $\mathrm{Mg}$, can cause deterioration of the soil structure by the dispersion of the colloids and, therefore, cause the macropores to become clogged, causing a reduction in the infiltration of water and gases (HOMEM et al., 2014).

Another problem resulting from the application of SW is the ability to cause soil salinization, due to the presence of $\mathrm{Na}$ (OLIVEIRA et al., 2000). The impacts caused on soil properties by $\mathrm{Na}$ will depend greatly on the amount and frequency of SW application. This nutrient is monovalent and has a large hydrated ray, so it has low affinity for the negative charges of the soil. Thus, Na present in the soil solution can be rapidly leached to the subsurface layers, if there is a downward flow of water (ALMEIDA et al., 2008).

At the highest applied dose of SW, $800 \mathrm{~m}^{3}$ $\mathrm{ha}^{-1}$, for both types of C. citriodora planting, there was a decrease in soil $\mathrm{Na}$ content. This drop may have been caused by the leaching of this cation to deeper layers due to the high volume of liquid applied, which associated to a soil of sandy texture may have intensified even more the leaching process.

When comparing the Na content in the soil, between the two forms of planting, the double lines presented higher concentrations of this nutrient. The cations such as $\mathrm{Ca}$ and $\mathrm{Mg}$. In planting in double lines, a higher $\mathrm{K} / \mathrm{T}$ ratio was observed in relation to planting in single lines, due to the higher concentration of this nutrient in the double row, as previously explained.

There was a difference between the SW rates and the $C$. citriodora planting type for the $\mathrm{Na}$ contents in the soil (Table 4 and Figure 3 ).

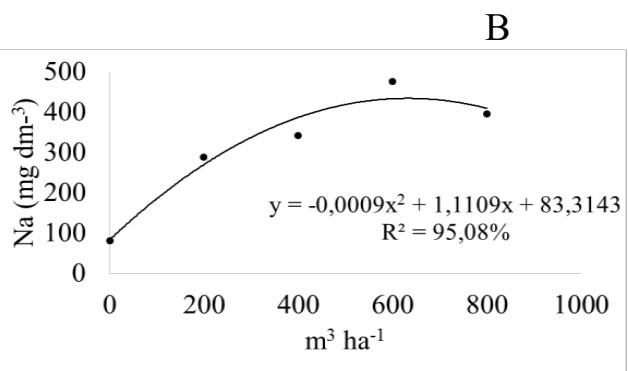

fact of finding higher $\mathrm{Na}$ content in the planting in double lines in relation to the simple lines, could be related to the greater Urochloa decumbens vegetation, retaining more the $\mathrm{SW}$, increasing the absorption by the soil.

$\mathrm{Na}$ is present in large quantities in $\mathrm{SW}$, because $\mathrm{NaCl}$ (Sodium Chloride) is added in the feed as a palatabilizer, and consequently it is eliminated in the waste. The application of SW in the soil can cause salinization of the soil, interfering in the electrical conductivity, relation of nutrient absorption by the plants and can contribute to the dispersion of the clay, being able to cause a waterproofing of the soil (MEURER et al., 2012). In plants, $\mathrm{Na}$ in excess impairs the germinative, vegetative and productive behavior by direct action on the osmotic potential and potentially toxic ions (GONÇALVES et al., 2011).

Homem et al. (2014) evaluated four doses of SW $\left(0 ; 50 ; 100\right.$ and $\left.150 \mathrm{~m}^{3} \mathrm{ha}^{-1}\right)$ and verified that the $\mathrm{Na}$ concentration and the sodium saturation index increased with the SW applications in soil, 020 and $20-40 \mathrm{~cm}$.

\section{Copper and zinc content in the soil}

$\mathrm{Cu}$ levels in the soil differed only for the SW doses, where the regression tests were applied (Table 5 and Figure 4). 
Table 5. Average soil $\mathrm{Cu}$ and $\mathrm{Zn}$ contents under two C. citriodora arrangements, single lines and double lines, with application of five different doses of swine wastewater.

\begin{tabular}{|c|c|c|c|c|}
\hline \multirow{2}{*}{$\mathrm{m}^{3} \mathrm{ha}^{-1}$} & $\begin{array}{l}\text { SL } \\
\mathrm{Cu} \\
\end{array}$ & DL & $\begin{array}{l}\text { SL } \\
\mathrm{Zn}\end{array}$ & DL \\
\hline & \multicolumn{4}{|c|}{ 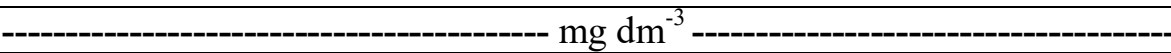 } \\
\hline 0 & 0.84 & 1.22 & 1.76 & 1.94 \\
\hline 200 & 2.08 & 1.92 & 2.10 & 2.58 \\
\hline 400 & 3.02 & 3.30 & 2.94 & 3.72 \\
\hline 600 & 4.24 & 4.52 & 3.80 & 4.48 \\
\hline 800 & 5.02 & 2.52 & 2.02 & 4.34 \\
\hline Average & $3.04^{\mathrm{ns}}$ & $2.70^{\mathrm{ns}}$ & $2.52 \mathrm{a}$ & $3.41 \mathrm{~b}$ \\
\hline CV (\%) & 49.24 & & 48.37 & \\
\hline
\end{tabular}

$(*)$ Values followed by lowercase letters in the line do not differ from each other by the Tukey test $(\mathrm{P}<0.05)$. Lowercase letters refers to the comparison between the planting arrangements single lines (SL) and double lines (DL). Ns: not significant $(\mathrm{P}>0.05)$.

A

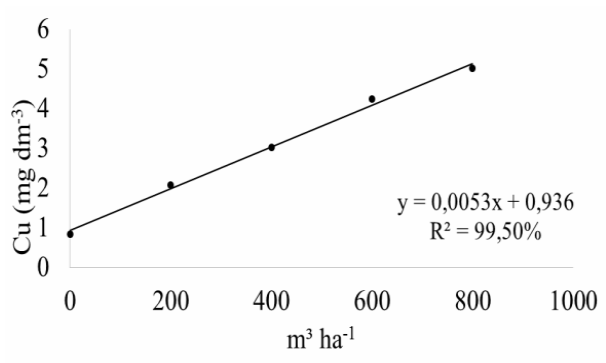

B

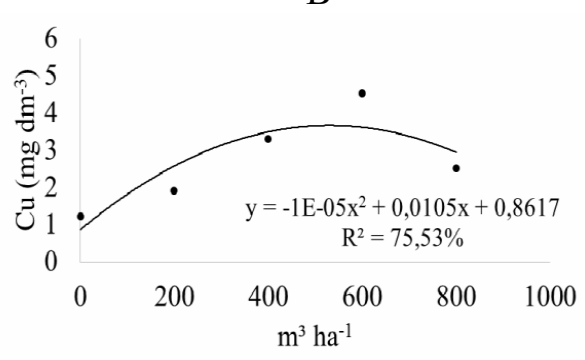

Figure 4. $\mathrm{Cu}$ content in the soil $\left(\mathrm{mg} \mathrm{dm}^{-3}\right)$, in single lines $(\mathrm{A})$ and double lines (B) of C. citriodora, as a function of swine wastewater doses.

It is observed that for the double-line planting, the highest concentration of $\mathrm{Cu}$ was 3.62 $\mathrm{mg} \mathrm{dm}$ at a dose of $525 \mathrm{~m}^{3} \mathrm{ha}^{-1}$. This value, according to CFSEMG (1999), is well above the value considered high, which is $1.8 \mathrm{mg} \mathrm{dm}^{-3}$. $\mathrm{Cu}$ is present in the rations, and approximately 70 to $95 \%$ is excreted, without being digested by the animal (PERDOMO; CAZZARÉ, 2001). Several studies report the increase of $\mathrm{Cu}$ in the soil after the application of SW, mainly in the superficial layers, being an indicative to show the soil quality in which SW is applied.

Silva and Mendonça (2007) stated that among the heavy metals, $\mathrm{Cu}$ is one of the least mobile in the soil due to its strong adsorption in organic and inorganic colloids. Girotto (2007), after seven years of application of SW, observed an increase in $\mathrm{Cu}$ and $\mathrm{Zn}$ levels in the soil and the movement of these in its profile.

When the highest dose of SW was applied, it was observed that there was a drop in $\mathrm{Cu}$ concentration in the soil when C. citriodora was planted in double lines. The same behavior was not observed in the $\mathrm{Cu}$ content in the planting in single lines. It is believed that pasture between the single lines of $C$. citriodora was able to retain more $\mathrm{Cu}$ because it presents a larger space occupied by forage, which may have produced a greater amount of organic matter in the soil, and contributed to a higher adsorption of $\mathrm{Cu}$ on the colloids.

So, for the single-line planting of $C$. citriodora, it was observed that the increase of $\mathrm{Cu}$ occurred in a linear way, and to the extent that increased the doses of SW, increased its concentration in the soil. Prior et al., (2015), applying five doses of SW $(0 ; 112.5 ; 225 ; 337.5$ and $450 \mathrm{~m}^{3} \mathrm{ha}^{-1}$ ) in maize crop showed an increase in $\mathrm{Cu}$ concentration in the soil, as the doses increased.

$\mathrm{Cu}$ is an essential element for plants, as it participates in the metabolism of carbohydrates, nitrogen, lignin and chlorophyll synthesis (MARSCHNER, 1995; FILHO, 2005). However, these nutrients in high amounts can become toxic to plants. Most plants show symptoms of toxicity such as necrosis and reduced growth of the root system (SOARES et al., 2000), necrosis of the leaves, early defoliation and decrease of the aerial growth of the plant.

There was no interaction between the SW rates and the planting type for the $\mathrm{Zn}$ content in the soil, with only significant differences for the doses and for the lines (Table 5 and Figure 5). 

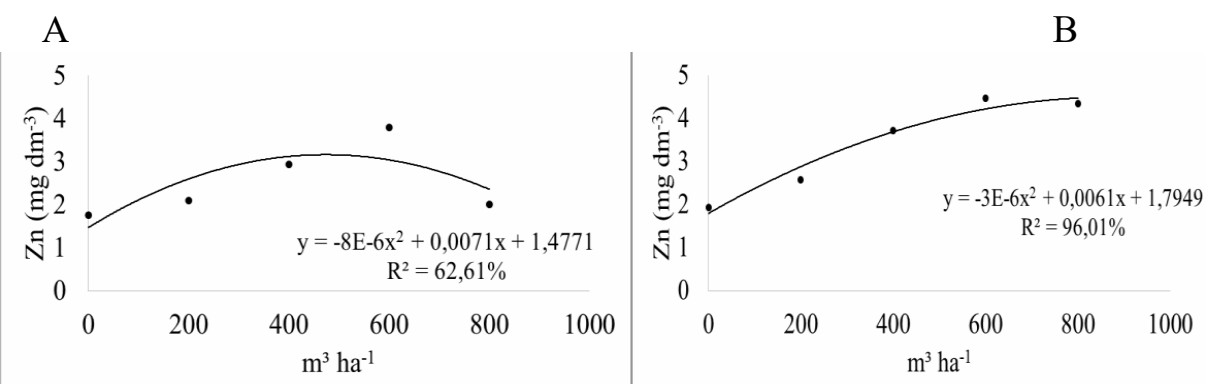

Figure 5. Zn content in the soil $\left(\mathrm{mg} \mathrm{dm}^{-3}\right)$, in single lines (A) and double lines (B) of C. citriodora, as a function of swine wastewater rates.

With increasing doses of SW in the single and double lines, there was an increase in $\mathrm{Zn}$ content. The values observed in Table 5, for the single and double lines, in the absence of SW, were classified as good $\left(1.6-2.2 \mathrm{mg} \mathrm{dm}^{-3}\right)$. After application of SW, the contents were classified as good $\left(1.6-2.2 \mathrm{mg} \mathrm{dm}^{-3}\right)$ to high $\left(>2.2 \mathrm{mg} \mathrm{dm}^{-3}\right)$ (CFSEMG, 1999). Like $\mathrm{Cu}, \mathrm{Zn}$ is also present in swine rations, and $70-95 \%$ is also excreted in feces and urine. This nutrient is considered a heavy metal, and its accumulation in the soil can cause toxicity to plants. Several studies have already evidenced the increase of $\mathrm{Zn}$ by the application of SW. With the application of SW, it was verified that the levels went from good to very high, according to the classification of CFSEMG (1999). This proves the ability of SW to increase soil $\mathrm{Zn}$ levels.

Smanhotto et al. (2010) evaluated four doses of SW $\left(0 ; 100 ; 200\right.$ and $\left.300 \mathrm{~m}^{3} \mathrm{ha}^{-1}\right)$, which showed an increase in $\mathrm{Zn}$ content with the increase of the dose, where the highest dose applied resulted in the highest accumulation of $\mathrm{Zn}$. Similar behavior was observed by Bertol (2005) who, with the application of $60 \mathrm{~m}^{3} \mathrm{ha}^{-1}$ of $\mathrm{SW}$, verified a $\mathrm{Zn}$ concentration 26 times higher in relation to the control plot and to mineral fertilization. Freitas et al. (2005) also verified increases in $\mathrm{Zn}$ concentration in the soil with the application of SW. In both plantations, at a dose of $800 \mathrm{~m}^{3} \mathrm{ha}^{-1}$, a reduction in the $\mathrm{Zn}$ contents was verified. It is believed that the high volume of liquid applied interfered directly with these results. The concentration in the double lines was higher in relation to the single line for the Zn content.

$\mathrm{Zn}$ is an essential micronutrient for plants because it is a structural component of many proteins and is particularly indispensable for their growth (LI et al., 2002). Zn deficiency can reduce grain yield and weaken disease resistance, decrease nutritional quality, cause drastic reduction of protein synthesis, cause reduced growth, small and poorly shaped leaves, and internerval chlorosis due to the participation of $\mathrm{Zn}$ in formation of chlorophyll (MARENCO; LOPES, 2009; BROADLEY et al., 2007). At high concentrations, this metal is potentially toxic (LI et al., 2002). The toxicity of Zn in plants leads to a reduction in both shoot dry matter production and root biomass, necrosis of the radicle in contact with the soil, death of the seedlings and inhibition of plant growth (CARNEIRO; SIQUEIRA; MOREIRA, 2002).

\section{Organic matter and organic carbon content in the soil}

There was no increase in OM and OC in the soil with the application of SW. There was a significant difference only for the $C$. citriodora planting lines (Table 6).

Table 6. Average organic matter (OM) and organic carbon (OC) soil content in the C. citriodora plantation performed in single and double lines, as a function of swine wastewater doses.

\begin{tabular}{|c|c|c|c|c|}
\hline Dose & $\mathrm{SL}$ & DL & $\mathrm{SL}$ & DL \\
\hline \multicolumn{5}{|c|}{$M$} \\
\hline $\mathrm{m}^{3} \mathrm{ha}^{-1}$ & ------- & --------- & . & ----- \\
\hline$\overline{0}$ & 3.40 & 2.30 & 2.01 & 1.33 \\
\hline 200 & 3.54 & 2.14 & 2.05 & 1.24 \\
\hline 400 & 3.38 & 2.46 & 1.96 & 1.43 \\
\hline 600 & 3.70 & 2.46 & 2.14 & 1.43 \\
\hline 800 & 3.12 & 2.24 & 1.81 & 1.30 \\
\hline Average & $3.44 \mathrm{a}$ & $2.32 \mathrm{~b}$ & $1.99 \mathrm{a}$ & $1.34 \mathrm{~b}$ \\
\hline
\end{tabular}

$\left(^{*}\right)$ Values followed by lowercase letters in the line do not differ from each other by the Tukey test $(\mathrm{P}<0.05)$. Lowercase letters refers to the comparison between the planting arrangements single lines (SL) and double lines (DL). 
The different doses did not increase the soil OM content (Table 6), several factors may have contributed to this result, highlighting the low OM content found in SW. In the absence of SW, the soil already had levels considered average for OM, according to CFSEMG (1999), which makes it more difficult to elevate. In degraded soils, the application of SW promotes an increase in OM contents that can be observed more quickly. Scherer, nesi and massotti (2010) conducted studies in which the application of SW also did not increase soil OM contents. Similar results were found by Caovilla et al. (2010), who did not find increase in OM content with SW application. According to Cunha (2009), the increment of $\mathrm{OM}$ is due to the increase in soil deposition of dry matter, aerial part and roots of the crops, than to the own OM content of SW.

Assmann et al. (2006) did not observe an increase in OM content with the application of SW. According to the authors, intrinsic characteristics of the manure used must be considered, in which the quality of the organic compounds may determine a greater or less accumulation of OM in the soil, since depending on the treatment used, there is a reduction in OM concentration. Probably, before the experiment was installed, OM was in equilibrium, and after the application of SW, it increased the soil microbiota, causing an imbalance, not raising soil contents.

The lower soil OM content in the doubleline planting may have occurred due to the inherent characteristics of the soil, due to the greater contribution of the vegetation and root system of $C$. citriodora and Urochloa grassland, which may have caused an imbalance, reducing its value, when comparing to a single-line planting that presents a larger space occupied by the forage.

\section{CONCLUSIONS}

The planting done in double lines provides higher levels of nutrients in the soil, under the application of swine wastewater.

Swine wastewater increased levels of potassium, sodium and heavy metals, such as copper and zinc in the soil.

The $200 \mathrm{~m}^{3} \mathrm{ha}^{-1}$ dose of swine wastewater provides adequate levels for most nutrients.

RESUMO: O confinamento de suínos destaca-se como grande gerador de águas residuárias de suinocultura (ARS). O destino final de resíduos gerados é atualmente uma preocupação da sociedade, uma vez que, se manejados de forma inadequada, podem provocar sérios impactos ao meio ambiente. Uma das alternativas é o uso da ARS como fonte de nutrientes, que após a mineralização da matéria orgânica, são disponibilizados para as plantas. O objetivo do trabalho foi comparar os atributos químicos do solo sob dois arranjos de plantio, em linhas simples e duplas de Corymbia citriodora. Foram implantados dois experimentos na fazenda Bonsucesso, em Uberlândia-MG, sendo o primeiro com C. citriodora em linhas simples, com cinco plantas por parcela, com espaçamento de dois metros entre plantas e 15 metros entre linhas. $\mathrm{O}$ segundo experimento foi com C. citriodora em linhas duplas, com dois metros entre plantas na linha, três metros entre linhas na parcela e 15 metros entre as linhas duplas de $C$. citriodora. O delineamento estatístico foi em blocos ao acaso. Os tratamentos utilizados foram cinco doses de ARS $\left(0 ; 200 ; 400 ; 600\right.$ e $\left.800 \mathrm{~m}^{3} \mathrm{ha}^{-1}\right)$ com cinco repetições. A aplicação das doses de ARS foram parceladas na estação da seca, nos meses de junho, julho e agosto. Foram avaliadas as características químicas do solo, na camada de $0-20 \mathrm{~cm}$ de profundidade. O plantio realizado em linhas duplas de $C$. citriodora proporcionou maiores teores de nutrientes no solo. A aplicação de água residuária de suinocultura elevou os teores de potássio e de metais pesados como o cobre e o zinco. A dose de $200 \mathrm{~m}^{3} \mathrm{ha}^{-1}$ proporcionou teores adequados para maioria dos nutrientes presentes no solo.

PALAVRAS-CHAVE: Dejetos de suínos. Fertirrigação. Metais pesados. Salinização do solo. Sistema silvipastoril.

\section{REFERENCE}

ABREU NETO, M. S. Tratamento de águas residuárias de suinocultura em reator anaeróbio compartimentado seguido de reator UASB. 2007. 170 f. Dissertação (Mestrado) - Universidade Estadual Paulista, Jaboticabal, 2007. 
ALMEIDA, H. C.; ERNANI, P. R.; ALBUQUERQUE, J. A.; JUNIOR, J. M.; ALMEIDA, D. Influência da adição de um resíduo alcalino da indústria de papel e celulose na lixiviação de cátions em um solo ácido. Revista Brasileira de Ciência do Solo, Viçosa, v. 32, n. 4, p. 1775-1784, 2008. https://doi.org/10.1590/S010006832008000400042

ANDRADE, A. M.; GOMES, S. S. Influência de alguns fatores não genéticos sobre o teor de óleo essencial em folhas de Eucaliptus citriodora Hook. Floresta ambiente, v. 7, n. 1, p. 181-189, 2000.

ASSMANN, A. P.; SANTOS, I.; ASSMANN, J. M.; BRAIDA, J. A.; MALAGI, G. Efeito de doses crescentes de esterco líquido de suínos na intensidade de antracnose e produtividade de soja. Synergismus scyentifica UTFPR, Pato Branco, v.1, n.1-4, p.1- 778, 2006.

Associação Brasileira de Criadores de Suínos, 2017. Disponível em:

$<$ http://www.abcs.org.br/component/content/article/89-noticias-destaque-pag inicial/2386-suinoculturabrasileira-tem-boas-perspectivas-para-2017>. Acesso em: 14 fev. 2017.

AYERS, R. S.; WESTCOT, D. W. A qualidade de água na agricultura. 2.ed. Campina Grande: UFPB, FAO, 1999, 153p.

BERTOL, O. J. Contaminação da água de escoamento superficial e da água perolada pelo efeito de adubação mineral e adubação orgânica em sistema de semeadura direta. 2005. 209 f. Tese (Doutorado) Universidade Federal do Paraná, Curitiba, 2005.

BERTONCINI, E. I. Dejetos da suinocultura - desafios para o uso agrícola. Pesquisa \& Tecnologia, São Paulo, v. 8, n. 2, 2011.

BROADLEY, M.R.; WHITE, P.J.; HAMMOND, J.P.; ZELKO, I.; LUX, A. Zinc in plants. New Phytologist, v. 4, n. 173, p. 677-702, 2007. https://doi.org/10.1111/j.1469-8137.2007.01996.x

CAOVILlA, F. A.; SAMPAIO, S. C.; SMANHOTTO, A.; NÓBREGA, L. H. P.; QUEIROZ, M. M. F.; GOMES, B. M. Características químicas de solo cultivado com soja e irrigado com água residuária da suinocultura. Brasileira de Engenharia Agrícola e Ambiental, Campina Grande, v.14, n.7, p.692-697, 2010. https://doi.org/10.1590/S1415-43662010000700002

CARNEIRO, M. A. C.; SIQUEIRA, J. O.; MOREIRA, F. M. S. Comportamento de espécies herbáceas em misturas de solo com diferentes graus de contaminação com metais pesados. Pesquisa Agropecuária Brasileira, Brasília, v. 37, n. 11, p. 1629- 1638, 2002. https://doi.org/10.1590/S0100-204X2002001100015

CERETTA, C. A.; BASSO, C. J.; VIEIRA, F. C. B.; HERBES, M. G.; MOREIRA, I. C. L.; BERWANGER, A.L. Dejeto líquido de suínos: I - perdas de nitrogênio e fósforo na solução escoada na superfície do solo, sob plantio direto. Ciência Rural, Santa Maria, v. 35, n. 6, p. 1296-1304, 2005. https://doi.org/10.1590/S010384782005000600011

Comissão de Fertilidade do Solo do Estado de Minas Gerais. Recomendações para o uso de corretivos e fertilizantes em Minas Gerais - $5^{\mathbf{a}}$ Aproximação. Antonio Carlos Ribeiro, Paulo Tácito Gontijo Guimarães, Victor Hugo Alvarez V., Editores. - Viçosa, MG, 1999. 359p.

CUNHA, J. L. Impacto ambiental em sistema de pastagem sob aplicações de esterco líquido de suínos. 2009. 91 f. Tese (Doutorado) - Universidade Federal de Uberlândia, Uberlândia, 2009.

DAL BOSCO, T. C. Poluição difusa decorrente da aplicação de água residuária da suinocultura em solo cultivado com soja sob condições de chuva simulada. 2007, 128 f. Dissertação (Mestrado) - Universidade Estadual do Oeste do Paraná, Cascavel, 2007. 
DOGENSKI, M. Extração do óleo essencial e oleoresina das folhas de Corymbia citriodora utilizando $\mathrm{CO}_{2}$ em condições sub e supercríticas. 2013. 144 f. Dissertação (Mestrado) - Universidade de São Paulo, Pirassununga, 2013.

EMBRAPA. Manual de métodos de análise de solos. Dados eletrônicos. Rio de Janeiro: Embrapa Solos, 2011.230 p.

EMBRAPA. Sistema brasileiro de classificação de solos. 3. ed. Brasília. Embrapa Solos, 2013. 353 p.

EMBRAPA. Sistema brasileiro de classificação de solos. 5. ed. Brasília: Embrapa Solos, 2018. 356 p.

FERREIRA, D. F. Análises estatísticas por meio do Sisvar para o Windows versão 4.0 In: Reunião anual da região brasileira da sociedade internacional biometria, 45.000, São Paulo. Anais..., São Paulo: UFSCAR, 2000. p. $255-258$.

FILHO, H. G. Cobre na planta. In: UNIVERSIDADE ESTADUAL PAULISTA. FACULDADE DE CIÊNCIAS AGRONÔMICAS. Departamento de Recursos Naturais. Ciência do Solo, 2005.

FRANCO, D. Avaliação do desempenho de gotejadores com uso de água residual na suinocultura. 2015, 46 f. Dissertação (Mestrado) - Universidade Estadual Paulista, Botucatu, 2015.

FREITAS, W.S.; OLIVEIRA, R.A.; CECON, P.R.; PINTO, F.A.; GALVÃO, J.C.C. Efeito da aplicação de águas residuárias de suinocultura em solo cultivado com milho. Engenharia na Agricultura, Viçosa, v.13, n.2, p.95-102, 2005.

GIROTTO, E. Cobre e zinco no solo sob uso intensivo de dejeto líquido de suínos. 2007. 121 f. Dissertação (Mestrado), Universidade Federal de Santa Maria, Santa Maria, 2007.

GOMES, F.P. Curso de estatística experimental. 11.ed. São Paulo: Nobel, 1985. 466p.

GONÇALVES, I. V. C.; FREIRE, M. B. G. S.; SANTOS, M. A.; SOUZA, E. R.; FREIRE, F. J. Alterações químicas de um Neossolo Flúvico irrigado com águas salinas. Revista Ciência Agronômica, Ceará, v. 42, p. 589-596, 2011.

HESPANHOL, I. Potencial de reúso de água no Brasil: agricultura, indústria, município e recarga de aqüíferos. In: MANCUSO, P. C. S.; SANTOS, H. F. (Editores). Reúso de Água. Barueri: Manole, 2003. p. 37-96. https://doi.org/10.21168/rbrh.v7n4.p75-95

HOMEM, B. G. C.; NETO, O. B. A.; CONDE, M. S.; SILVA, M. D.; FERREIRA, I. M. Efeito do uso prolongado de água residuária da suinocultura sobre as propriedades químicas e físicas de um Latossolo Vermelho-Amarelo. Científica, São Paulo, v. 42, n. 3, p. 299-309, 2014. https://doi.org/10.15361/19845529.2014v42n3p299-309

LI X.; CHEN, B.; FENG, G.; CHRISTIE, P. Role of arbuscular mycorrhyzal fungi in alleviation of Zn phytotoxicity and mineral nutrition of host plants. In: 17th WCSS, Thailand, 2002.

MARENCO, R. A.; LOPES, N. F. Fisiologia Vegetal: Fotossíntese, respiração, relações hídricas e nutrição mineral. Universidade Federal de Viçosa, 2009. p.267- 297.

MARSCHNER, H. Mineral nutrition of higher plants. London: Academic Press, 1995. 889 p.

MEURER, E. J.; BISSANI, C. A.; CARMONA, F. C. Solos ácidos e solos afetados por sais. In: MEURER, E.J. (ED.) Fundamentos de química do solo. 5 ed. Porto Alegre: EVANGRAF, 2012. 
MINISTÉRIO DA AGRICULTURA PECUÁRIA E ABASTECIMENTO. Ministério da agricultura - suínos. 2014. Disponível em: http://www.agricultura.gov.br/animal/especies/suinos. Acesso em: 22 jan. 2017.

OLIVEIRA, R. A.; CAMPELO, P. L. G.; MATOS, A. T.; MARTINEZ, M. A.; CECON, P. R. Influência da aplicação de águas residuárias de suinocultura na capacidade de infiltração de um solo Podzólico VermelhoAmarelo. Revista Brasileira de Engenharia Agrícola e ambiental, Campina Grande, v.4, n.2, p.263-267, 2000. https://doi.org/10.1590/S1415-43662000000200022

PERDOMO, C. C.; CAZZARÉ, M. Sistema Dalquim de tratamento de resíduos animais. Comunicado Técnico, 284. Concórdia: EMBRAPA/CNPSA, 2001.

PRIOR, M.; SAMPAIO, S. C.; NÓBREGA, L. H. P.; DIETER, J.; COSTA, M. S. S. M. Estudo da associação de água residuária de suinocultura e adubação mineral na cultura do milho e no solo. Engenharia Agrícola, Jaboticabal, v.35, n.4, p.744-755, 2015. https://doi.org/10.1590/1809-4430-Eng.Agric.v35n4p744-755/2015

SCHERER, E. E.; NESI, C. N.; MASSOTTI, Z. Atributos químicos do solo influenciados por sucessivas aplicações de dejetos suínos em áreas agrícolas de Santa Catarina. Revista Brasileira de Ciência do Solo, Viçosa, v.34, p.1375-1383, 2010. https://doi.org/10.1590/S0100-06832010000400034

SEGRANFREDO, M. A. Dejetos Animais - A dupla face benefícios e prejuízos, Concórdia, 2004.

SIGMA PLOT. Sigma Plot Instrumentation Framework. 2015.

SILVA, I. R.; MENDONÇA, E. S. Matéria orgânica do solo. In: NOVAIS, R.F.; ALVAREZ V.V.H.; BARROS, N.F.; FONTES, R.L.F.; CANTARUTTI, R.B.; NEVES, J.C.L., eds. Fertilidade do solo. Viçosa, MG, Sociedade Brasileira de Ciência do Solo, 2007. p.275-374.

SMANHOTTO, A.; SOUSA, A. P.; SAMPAIO, S. C.; NÓBREGA, L. H. P.; PRIOR, M. Cobre e zinco no material percolado e no solo com a aplicação de água residuária de suinocultura em solo cultivado com soja. Engenharia Agrícola, Jaboticabal, v. 30, n. 2, p.346-357, 2010. https://doi.org/10.1590/S010069162010000200017

SOARES, C. R. F. S.; SIQUEIRA, J. O.; CARVALHO, J. G.; MOREIRA, F. M. S.; GRAZZIOTTI, P. E. Crescimento e nutrição mineral de Eucalyptus maculata e Eucalyptus urophylla em solução nutritiva com concentração crescente de cobre. Revista Brasileira de Fisiologia Vegetal, Campinas, v. 12, n. 3, p. 213-225, 2000. https://doi.org/10.1590/S0103-31312000000300005

WERLE, R.; GARCIA, R. A.; ROSOLEM, C. A. Potassium Leaching as Affected by Soil Texture and Potassium Availability. Revista Brasileira de Ciência do Solo, Viçosa, v. 32, p. 2297-2305, 2008. https://doi.org/10.1590/S0100-06832008000600009 